\title{
Pollen record of disturbed topsoil as an indirect measurement of the potential risk of the introduction of non-native plants in maritime Antarctica
}

\author{
Eduardo Fuentes-Lillo ${ }^{1,2}$, J. Max Troncoso-Castro², Marely Cuba-Díaz ${ }^{1}$ and Mauricio J. Rondanelli-Reyes²*
}

\begin{abstract}
Background: This is a study of current pollen rain on soil disturbed by human use on the Fildes Peninsula, King George Island, South Shetland Islands. A sector strongly affected by human activity, an area between the Eduardo Frei Montalva Chilean Air Force (FACH) base and the Professor Julio Escudero base of the Chilean Antarctic Institute (INACH) were sampled. A less used sector associated with scientific activity and controlled tourism, Ardley Island, and an area of low human activity, the terminal moraine of the Collins glacier, were also sampled. The samples were collected in the southern summer of 2015 and kept in the Palynology and Plant Ecology Laboratory of the Los Angeles Campus of the Universidad de Concepción, Chile.

Findings: The area of greatest human activity concentrated the greatest diversity (12 taxa) of pollen grains. Three taxa are considered native to the region. Non-native taxa determined for this sector in turn had the greatest invasion (INV) factor. The dominant families were Brassicaceae and Asteraceae. The results for Ardley and Collins represent the cryptogamic flora and grasses typical of the ecosystem.

Conclusion: Under the current climate change scenario, the pollen rain in Antarctic soil, in addition to obeying the random patterns of its natural dispersion, could be interpreted as an indirect measurement of the potential risk of the passive transport of propagules to Antarctica mediated by human beings.
\end{abstract}

Keywords: Pollen rain, Climate change, Anthropization, Ice-free zones, Fildes Peninsula, South Shetland Islands

\section{Resumen}

La presente investigación es un estudio de la lluvia de polen actual en suelo perturbado por uso antrópico en la Península Fildes, Isla Rey Jorge, Islas Shetland del Sur. Se muestreó un sector fuertemente afectado por actividad humana en un área comprendida entre la base de la Fuerza Aérea de Chile (FACH) Eduardo Frei Montalva y la base del Instituto Antártico Chileno (INACH) Profesor Julio Escudero. Un sector con menos presión de uso, Isla Ardley, asociado con actividad científica y turismo controlado también fue estudiado. Finalmente, un tercer sector fue analizado, correspondiente a la morrena terminal del glaciar Collins, que presenta muy baja actividad humana. Las muestras fueron colectadas en el verano de 2015 y analizadas en el Laboratorio de Palinología y Ecología Vegetal del Campus Los Ángeles de la Universidad de Concepción, Chile. El área que presenta la mayor (Continued on next page)

\footnotetext{
* Correspondence: mrondane@udec.cl

${ }^{2}$ Laboratorio de Palinología y Ecología Vegetal, Departamento de Ciencia y

Tecnología Vegetal, Universidad de Concepción, Campus Los Angeles, Juan

Antonio Coloma 0201, Los Angeles, Bío-Bío, Chile

Full list of author information is available at the end of the article
} 


\begin{abstract}
(Continued from previous page)
concentración de actividad humana concentró la mayor diversidad de granos de polen (12 taxa). Tres taxa son considerados nativos para la región. Los taxa no nativos determinados para el sector presentaron a su vez, el mayor factor de invasión (INV). Las familias dominantes fueron Brassicaceae y Asteraceae. Los resultados para los sectores de Isla Ardley y glaciar Collins representaron la flora criptogámica y de pastos típicos del ecosistema. Bajo el presente escenario de cambio climático, la lluvia de polen determinada en suelo antártico podría estar reflejando además de la azarosidad propia de la dispersión natural una medida indirecta del riesgo potencial de un transporte pasivo de propágulos a Antártica mediado por el hombre.
\end{abstract}

Palabras-clave: Lluvia de polen, Cambio climático, Antropización, Zonas libres de hielo, Península Fildes, Islas Shetland del Sur

\section{Findings}

\section{Introduction}

In recent years, maritime Antarctica has undergone an extension of the growing season for terrestrial biota due to the accelerated increase in the region's temperature [1], which has caused winters to shorten, the spring thaw to occur earlier and freezing to occur later in the fall [2]. The Antarctic tundra is formed essentially by lichens, mosses, algae and hepatics, and characterized by a sparse representation of flowering plants [3]. This terrestrial biodiversity is confined to the ice-free areas that cover $0.34 \%$ of Antarctica [4], the particular value of which lies in it being a relatively pristine nature with very little anthropogenic influence. The simplicity and low diversity of the Antarctic terrestrial ecosystem renders it vulnerable to the impact of introduced species $[5,6]$. The improvement in growing conditions (increase in temperature and water availability) due to global warming not only favors the likelihood of colonization by new populations of the native species, but also the non-native ones $[7,8]$.

The most recent records of non-Antarctic species suggest the probability of being in the presence of a new means of arrival "assisted by man" of these non-native organisms, since more human activity also increases the contacts from different regions and between these and Antarctica $[9,10,6,11]$. The introduction routes of nonnative organisms have been closely related to the movement of people and logistics of scientific programs and, to a lesser extent, tourist operators $[5,6,11]$ as well as to areas of increased activity in the summer and around the Antarctic stations where the soil disturbance makes these areas more vulnerable to the microclimate for the establishment of non-native plants [5, 12].

Although there are few studies on pollen rain currently in maritime Antarctica, some have referred to the depositing of pollen as a good indicator of the direction and frequency of potential immigration of nonAntarctic plants or their remains to this ecosystem, mainly through a long-distance transport from subAntarctic territories [13, 14, 15]. The results of the taxonomic determination of these studies have shown that, generally, the pollen grains and spores found correspond mainly to species that represent the cryptogamic and vascular flora native to the Antarctic ecosystem as well as to that of sub-Antarctic species, mainly of herbaceous habit, such as Poaceae, Asteraceae, Brassicaceae and Apiaceae, considered aggressive species in the colonization of potentially available niches $[16,8,13]$.

Knowing the close relation between vegetation and pollen [17] and in light of the new ecophysiological scenario described for maritime Antarctica that increased human activity has brought as a result, one might wonder whether this human activity is fulfilling some role in the formation of the pollen pattern of ecosystems subject to heavy and sustained use pressure, like for example the Fildes Peninsula in the South Shetland Islands. And whether these results could be reflecting indirectly the potential hazard that something else more than pollen arrived in this ecosystem besides humans and their equipment.

\section{Methods}

During the southern summer of 2015 topsoil was sampled for pollen analysis in three sectors of the Fildes Peninsula (Fig. 1), each of which is subject to different use pressure. The sector between the Eduardo Frei Montalva Chilean air force base (FACH) and the Professor Julio Escudero base of the Chilean Antarctic Institute (INACH) has a constant flow of anthropic activities, either scientific, logistical and/ or tourist. This sector was divided into 10 sampling subsectors: runway (S1), lodging for guests of the FACH (S2), main fuel depot of the FACH (S3), entrance to Bellingshausen Russian base (S4), three sub-sectors corresponding to the dormitories of FACH logistics personnel - Module A (S5), Module B (S6) and Module C (S7) - Villa Las Estrellas, a permanent Chilean civiliansettlement on the peninsula (S8), the church of Villa Las Estrellas (S9) and the perimeter of the INACH Escudero base (S10).

Another sector sampled was Ardley Island (S11), which has a less constant flow of visits, restricted to scientific personnel who study the island and tourists who can circulate between Faro Point and the beginning of 


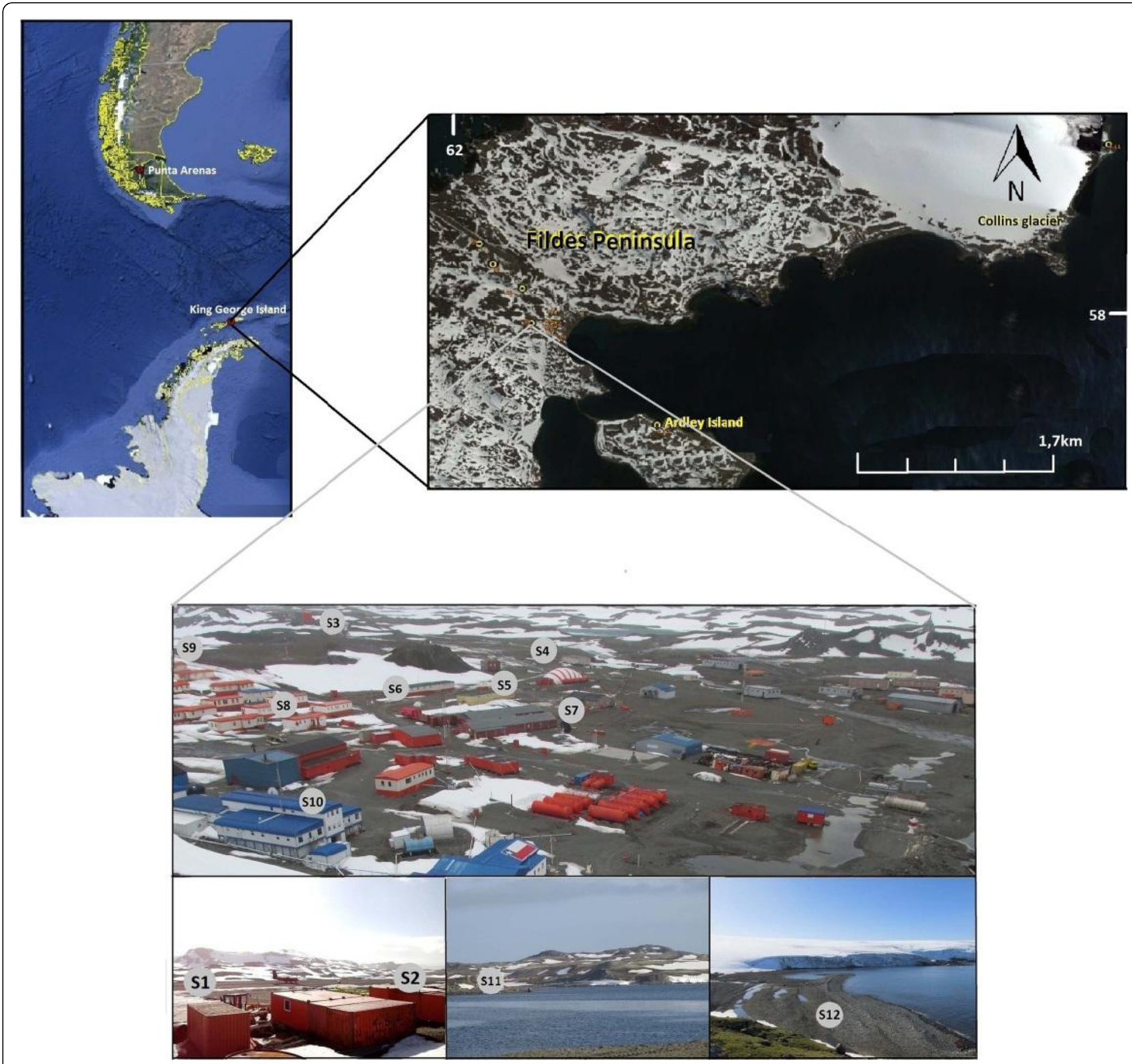

Fig. 1 Geographic location on the study area

Braillard Point. Finally, a third sector was sampled that has little human activity, which is the terminal moraine of the Collins Glacier (S12); the flow of people in this ecosystem is restricted to the scientific personnel who study the area.

The sampling consisted of drawing a $1 \mathrm{~m}^{2}$ quadrant in each sector and sub-sector.50 grams of topsoil $(1-2 \mathrm{~cm})$ were taken from each quadrant in triplicate. The samples were stored at $4{ }^{\circ} \mathrm{C}$ until transport to the Palynology and Plant Ecology Laboratory of the Universidad de Concepción, Los Ángeles campus. Sample preparation followed the classic methodology for palynology [18] with the addition of hydrofluoric acid and the use of acetolysis. Pollen were identified and counted using an Olympus CX31RTSF planachromatic trinocular microscope with a CCD Microimaging 5.1 MP camera and digitized using Micrometrics SE Premium 4 software. A specialized bibliography was used the taxonomic identification of the palynomorphs $[19,20]$.

Using a detrended correspondence analysis (DCA) the pollen rain data were examined, including all the taxa determined in the soil samples. This method of indirect classification was applied to the pollen sum matrix and used to group the study sectors with a benchmark invasion factor (WRA-CH) for each taxon determined $[21,16]$, which we will call the invasion index (INV). 
This (INV) was calculated by adding the WRA-ch indices of all the species that belong to a particular Family and then dividing that sum by the total number of species in that Family (Additional file 1).

\section{Results}

Table 1 indicates the taxonomy and abundances of the palynomorphs identified in this study.12 taxa were determined, of which 3 are considered native to Antarctica, spores from the moss Didymodon $s p$, lichen spores and Poaceae pollen. Also represented in the record are one taxon belonging to gymnosperms (Podocarpaceae), six families belonging to dicotyledonous angiosperms (Nothofagaceae, Fabaceae (cf. Galega officinalis), Asteraceae ( $c f$. Taraxacum officinale), Brassicaceae, Apiaceae, Chenopodiaceae) and one family belonging to monocotyledonous angiosperms (Juncaceae). The most representative families were Brassicaceae (22.94\%), Poaceae (12.47 \%) and Asteraceae $(6.45 \%)$. With respect to the sample sites, those that presented the highest concentration of palynomorphs were S9 (10.91\%), S5 (10.48\%), S6 (9.35\%) and S7 (6.46\%).

The DCA (Fig. 2) showed a classification trend, in which the sites subject to constant and frequent human activity (S5, S6, S7 and S9) were grouped with $75 \%$ of the taxa determined, those that in turn presented the highest invasion indices(INV). A second classification trend, however, grouped $17 \%$ of the taxa found in S10, S11 and S12 sectors with less frequent human activity, as corresponding to pollen from the family Poaceae (possibly Deschampsia antarctica) and spores of the genera Diporites on crustose lichens native to Antarctica and which represent the predominant flora in these sectors. Sites S3 and S4 had no bearing on the grouping.

\section{Discussion}

The taxonomic determination of pollen and spores in this study agrees with previous studies for this and other locations in Antarctica [13, 22], but it also reveals that botanical families widely recognized for their role as aggressive species in the competition for colonization of the available niches $[23,24]$ are precisely those that appear in greater abundance and coincide in their distribution with the sampling sites with sustained anthropic activity. Brassicaceae and Asteraceae are the dominant botanical families in this study in terms of the number of pollen grains recorded. Both families have been recorded superior taxonomic group comprised of several species with high values on invasion indices $[21,16]$ and as benefitting from a greater production of male gametes and an extended anthesis resulting from the greater $\mathrm{CO}^{2}$ concentration in the atmosphere $[25,26]$. Many of these species have a cosmopolitan distribution and a wide presence in the sub-Antarctic territories close to maritime Antarctica; therefore, they must be considered species of concern and high surveillance when conducting regulatory controls of the immigration of their propagules to maritime Antarctic territories $[8,27]$. It is interesting in our study to verify that the largest number of pollen grains from the families Brassicaceae and Asteraceae are presented on the sampling site with the greatest land use and pressure, corresponding to the sector between the FACH and INACH bases, but concentrated in the sub-sectors sampled from the camps for Chilean air

Table 1 Abundance of pollen and spores determined for the sampling sites (Additional file 2)

\begin{tabular}{|c|c|c|c|c|c|c|c|c|c|c|c|c|}
\hline & Runway & $\begin{array}{l}\text { Lodging } \\
\text { for } \\
\text { Guest } \\
(\text { FACH })^{\text {a }}\end{array}$ & $\begin{array}{l}\text { Main } \\
\text { fuel } \\
\text { depot } \\
\text { (FACH) }\end{array}$ & $\begin{array}{l}\text { Entrance to } \\
\text { Bellingshausen } \\
\text { Russian Base }\end{array}$ & $\begin{array}{l}\text { FACH } \\
\text { module } \\
\text { (A) }\end{array}$ & $\begin{array}{l}\text { FACH } \\
\text { module } \\
\text { (B) }\end{array}$ & $\begin{array}{l}\mathrm{FACH} \\
\text { module } \\
\text { (C) }\end{array}$ & $\begin{array}{l}\text { Villa las } \\
\text { Estrellas }\end{array}$ & $\begin{array}{l}\text { Church } \\
\text { of Villa } \\
\text { las } \\
\text { Estrellas }\end{array}$ & $\begin{array}{l}\text { Escudero } \\
\text { Base } \\
(\text { INACH) }\end{array}$ & $\begin{array}{l}\text { Ardley } \\
\text { Island }\end{array}$ & $\begin{array}{l}\text { Collins } \\
\text { Glaciar }\end{array}$ \\
\hline $\begin{array}{l}\text { Didymodon sp. } \\
\text { (moss spores) }\end{array}$ & - & - & - & - & 3 & 1 & 1 & - & - & - & 114 & 90 \\
\hline Lichen spores & 3 & 1 & 6 & - & 2 & 1 & 4 & 1 & 5 & 2 & - & - \\
\hline Nothofagaceae & - & - & 1 & 5 & - & - & - & - & 2 & - & - & - \\
\hline Podocarpaceae & - & - & - & - & - & 1 & 2 & - & - & - & - & - \\
\hline $\begin{array}{l}\text { Chenopodiaceae/ } \\
\text { Amaranthaceae }\end{array}$ & - & - & - & - & 1 & - & - & - & - & - & - & - \\
\hline Apiaceae & - & - & - & - & 1 & - & 1 & - & 3 & - & - & - \\
\hline Brassicaceae & - & - & - & 1 & 34 & 20 & 11 & 1 & 36 & - & - & - \\
\hline Poaceae & - & - & - & - & - & - & 2 & - & - & - & 13 & 41 \\
\hline Juncaceae & - & - & - & - & - & - & - & - & - & - & - & 2 \\
\hline Fabaceae & - & - & - & - & - & 1 & - & - & - & - & - & - \\
\hline Asteraceae & - & - & - & - & 6 & 18 & 8 & - & 3 & - & - & 1 \\
\hline $\begin{array}{l}\text { Pollen } \\
\text { concentration }\end{array}$ & 537,42 & 1222,02 & 4023,25 & 1518,60 & 1232,15 & 7900,21 & 1948,17 & 598,23 & 4076,98 & 483,02 & 9609,23 & 38331,22 \\
\hline
\end{tabular}

${ }^{a}$ Chilean Air Force; ${ }^{b}$ Military dormitory; ${ }^{c}$ permanent Chilean civilian; ${ }^{\mathrm{d}}$ Chilean Antarctic Institute 


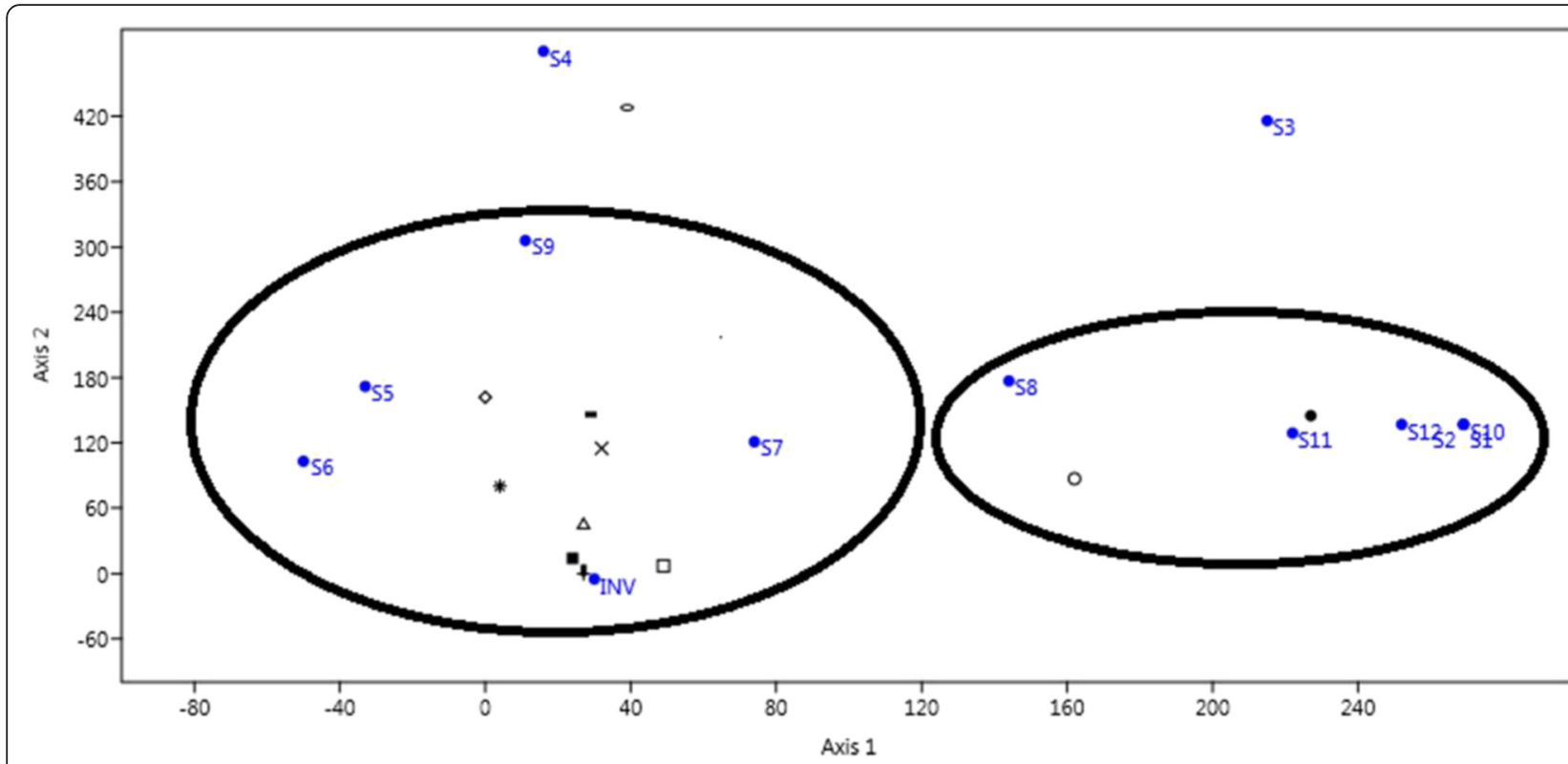

SYMBOLOGY

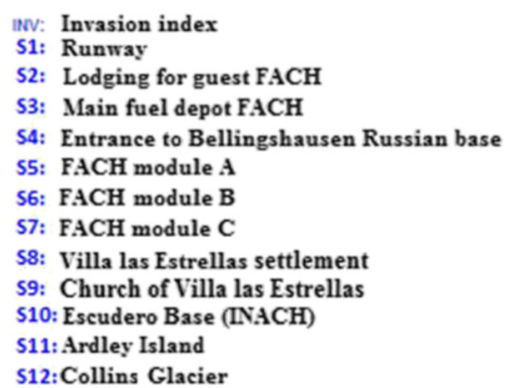

Fig. 2 DCA plot. Detrended correspondence analysis (DCA) based on the pollen composition through a north-south transect on the Fildes Peninsula, King George Island. Axis 1 (eigenvalue 0.7881) represents the spatial grouping of the sites and Axis2 (eigenvalue 0.5084) represents the spatial location of the pollen taxa identified in the topsoil samples. The data represented in the classification present an accumulated variance of $64.50 \%$

force personnel. This is not the case on other sites with equally abundant altered land such as the runway and the INACH Escudero base. This could be a reflection of sanitation protocols used and the precautionary safeguards regarding the controlled use of footwear and change of clothes being effective in avoiding the presence of plant microparticles. On the other hand, the pollen material determined for the Collins Glacier and Ardley Island ecosystems are related to the surrounding cryptogamic and gramineous flora corresponding to what has been described in other studies with respect to the numerous representation of spores from mosses and lichens [28] and the abundance of the gramineous pollen from the populations of Deschampsia antarctica [15].

If we consider that the sectors studied do not cover more than $4 \mathrm{~km}^{2}$ in total, that the pollen distribution to Antarctica from sub-Antarctic territories is a proven fact, that its random distribution is linked to the aggressive potential for dispersion of some recognized species and that our results show a pollen spectrum, in diversity and quantity, concentrated in nearby environments subject to human disturbance but not in ecosystems far from this pressure of use or under strict biosafety controls, we could infer that the transport, arrival and depositing of pollen in Antarctic soil would not only be obeying random patterns in its natural dispersion, but could be revealing an indirect measure of the degree of potential risk that the passive transport of propagules mediated by human beings and their associated equipment means under the current climate change scenario.

\section{Additional files}

Additional file 1: Calculation of the Invasion Index (INV). (XLSX $11 \mathrm{~kb}$ ) Additional file 2: Calculation of the pollen count. (XLSX $33 \mathrm{~kb})$ 


\section{Competing interests}

The authors declare that they have no competing interests.

\section{Authors' contributions}

EFL is the author of INACH PR_05-14. He conducted field work and participated in the preparation and determination of the pollen samples, statistical treatment of the results as well as preparation of the figures and tables. JMTC carried out field work and participated in the preparation and determination of the pollen samples. He is the author of Fig. 1, location map. MCD conducted field work, conceived the initial research idea and participated in the writing of the manuscript. MJRR supervised the laboratory work in relation to the preparation, observation and determination of the pollen samples. He participated in the original research idea. He directed and shaped the structure and writing of the final manuscript. All the authors read and approved the final manuscript.

\section{Acknowledgements}

This study was supported through the projects INACH PR_05-14 and INACH RG_02-13. The authors are grateful for the logistical support offered by the Air Force of Chile (FACH) and Correos de Chile. MJRR wishes to thank the Academic Vice-Rectory of the Universidad of Concepción for the authorized sabbatical leave that permitted, among other things, the implementation of this study. We also thank $\mathrm{H}$. Lowry for her assistance in revising the English.

\section{Author details}

${ }^{1}$ Laboratorio de Biotecnología y Estudios Ambientales, Departamento de Ciencia y Tecnología Vegetal, Universidad de Concepción, Campus Los Angeles, Juan Antonio Coloma 0201, Los Angeles, Bío-Bío, Chile. ' Laboratorio de Palinología y Ecología Vegetal, Departamento de Ciencia y Tecnología Vegetal, Universidad de Concepción, Campus Los Angeles, Juan Antonio Coloma 0201, Los Angeles, Bío-Bío, Chile.

Received: 17 November 2015 Accepted: 23 February 2016 Published online: 14 March 2016

\section{References}

1. Turner J, Colwell SR, Marshall GJ, Lachlan-Cope TA, Carleton AM, Jones PD, Lagun $V$, Reid PA, lagovkina S. Antarctic climate change during the last 50 years. Int J Climatology. 2005;25:279-94. doi:10.1002/joc.1130.

2. Lewis-Smith LRI. Plant colonisation response to climate change in the Antarctic. Folia Facultatis Scientiarium Naturalium Universitatis Masarykianae brunensis. Geographia. 2001;25:19-33.

3. Convey P. Antarctic terrestrial ecosystems: responses to environmental change. Polarforschung. 2005;75:101-11.

4. Peat HJ, Clarke A, Convey P. Diversity and biogeography of the Antarctic flora. J Biogeogr. 2007;34:132-46. doi:10.1111/j.1365-2699.2006.01565.x.

5. Chown SL, Huiskes AHL, Gremmen NJ, Lee JE, Terauds A, Crosbie K, Frenot Y, Hughes KA, Imura S, Kiefer K, Lebouvier M, Raymond B, Tsujimoto M, Ware C, Van de Vijver B, Bergstrom DM. Continent wide risk assessment for the establishment of non indigenous species in Antarctica. Proc Natl Acad Sci. 2012:109:4938-43. doi:10.1073/pnas.1119787109.

6. Frenot Y, Chown SL, Whinam J, Selkirk PM, Convey P, Skotnicki M, Bergstrom DM. Biological invasions in the Antarctic: extent, impacts and implications. Biol Rev. 2005;80:45-72. doi:10.1017/S1464793104006542.

7. Hughes KA, Ott S, Bolter M, Convey P. Colonisation processes. In: Bergstrom D, Convey $\mathrm{P}$, Huiskes AHL, editors. Trends in Antarctic Terrestrial and Limnetic Ecosystems. Dordrecht: Springer; 2006. p. 35-54. doi:10.1007/1-4020-5277-4_3.

8. Huiskes HL, Gremmen JM, Bergstrom DM, Frenot Y, Hughes KA, Imura S, Kiefer K, Lebouvier M, Lee JE, Tsujimoto M, Ware C, Vijver BV, Chown SL. Aliens in Antarctica: Assessing transfer of plant propagules by human visitors to reduce invasion risk. Biol Conserv. 2014;171:278-84. doi:10.1016/j. biocon.2014.01.038.

9. Convey P, Chown SL, Clarke A, Barnes K A, Bokhorst S, Cummings V, Ducklow HW, Frati F, Green TG, Gordon S, Griffiths HJ, Howard-Williams C, Huiskes HL, Laybourn-Parry J, Lyons WB, McMinn A, Morley SA, Peck LS, Quesada A, Robinson SA, Schiaparelli S, Wall DH. Ecological Monographs. 2014:84: 203-244. doi:10.1890/0012-9615-84.4.659

10. Cuba-Díaz M, Troncoso JM, Cordero C, Finot VL, Rondanelli-Reyes M. Juncus bufonius, a new non-nativevascular plant in King George Island, South Shetland Islands. Antarctic Sci. 2013;25:285-6.

11. Hughes KA, Convey P. The protection of Antarctic terrestrial ecosystems from inter- and intra-continental transfer of non-indigenous species by human activities: a review of current systems and practices. Global Environ Change. 2010:20:96-112. doi:10.1016/j.gloenvcha.2009.09.005.

12. Chwedorzewska KJ, Korczak M. Human impact upon the environment in the vicinity of Arctowski Station, King George Island, Antarctica. Polish Polar Res. 2010;31:45-60. doi:10.4202/ppres.2010.04

13. Kappen L, Straka H. Pollen and Spores Transport into the Antarctic*. Polar Biol. 1988:8:173-80. doi:10.1007/BF00443450.

14. Sharma C, Bera SK, Upreti DK. Modern pollen-spore rain in Schirmacher oasis. East Antarctica Current Sci. 2002:82:88-91.

15. Szczuka E, Giełwanowska I, Pidek IA, Seta L, Domaciuk M, Kołodziejsk W. Pollen of the Antarctic plants Colobanthus quitensis and Deschampsia antarctica and its representation in moss polsters. 2008;63:63-72. doi:10. 2478/v10067-008-0004-3

16. Fuentes N, Pauchard A, Sánchez P, Esquivel J, Marticorena A. A new comprehensive database of alien plant species in Chile based on herbarium records. Biol Invasions. 2013;15:847-58. doi:10.1007/s10530-012-0334-6.

17. Nascimento LD, Nogué S, Fernández-Lugo S, Méndez J, Otto R, Whittaker RJ, Willis KJ, Fernández-Palacios JM. Modern pollen rain in Canary Island ecosystems and its implications for the interpretation of fossil records. Rev Palaeobotany Palynology. 2015;214:27-39. doi:10.1016/j.revpalbo.2014.11.002

18. Faegri K, Iversen J. Textbook of Pollen Analysis. John Wiley \& Sons; 1989.

19. Beug HJ. Leitfaden der Pollenbestimmung. Stuttgart: Gustav Fischer Verlag; 2004

20. Heusser C. Pollen and spores of Chile. Modern types of the Pteridophyta, Gymnospermae and Angiospermae. Tucson, USA: Arizona University Press; 1971.

21. Fuentes N, Ugarte E, Kuhn I, Klotz S. Alien plants in southern South America. A framework for evaluation and management of mutual risk of invasion between Chile and Argentina. Biol Invasions. 2010;12:3227-36. doi:10.1007/ s10530-010-9716-9.

22. Smith, L. Exotic sporomorpha as indicators of potential immigrant colonists in Antarctica, Grana. 1991;30:2, 313-324, doi: 10.1080/00173139109431986.

23. Anderson JT, Gezon Z. Plasticity in functional traits in the context of climate change: a case study of the subalpine forb Boechera stricta (Brassicaceae). Glob Chang Biol. 2015;21:1689-703. doi:10.1111/gcb.12770.

24. Hughes KA, Convey P. Determining the native/non-native status of newly discovered terrestrial and freshwater species in Antarctica - Current knowledge, methodology and management action. J Environ Manage. 2012;93:52-66.

25. Beggs PJ. Impacts of climate change on aeroallergens: past and future. Clin Exp Allergy. 2004;34:1507-13. doi:10.1111/j.1365-2222.2004.02061.x.

26. Ziska HA, Caulfield FA. Rising CO2 and pollen production of common ragweed (Ambrosia artemisiifolia), a known allergy-inducing species: implications for public health. Aust J Plant Physiol. 2000;27:893-8. doi:10. 1071/PP00032

27. Lynch HJ, Crosbie K, Fagan WF, Naveen R. Spatial patterns of tour ship traffic in the Antarctic Peninsula region. Antarctic Sci. 2009;22:1-8. doi:10. 1017/S0954102009990654

28. Putzke J, Athanásio CG, Albuquerque MP, Victoria FC, Pereira A. Comparative study of moss diversity in South Shetland Islands and in the Antarctic Peninsula. Revista Chilena de Historia Natural. 2015;88:1-6. doi:10.1186/ s40693-014-0033-z.

\section{Submit your next manuscript to BioMed Central and we will help you at every step:}

- We accept pre-submission inquiries

- Our selector tool helps you to find the most relevant journal

- We provide round the clock customer support

- Convenient online submission

- Thorough peer review

- Inclusion in PubMed and all major indexing services

- Maximum visibility for your research

Submit your manuscript at www.biomedcentral.com/submit 